\title{
ASSESSMENT OF WILD CHERRY (PRUNUS AVIUM L.) CHOPPING AND UTILIZATION FOR BIOFUEL AND INVESTIGATION OF CHAFF PROPERTIES
}

\author{
Algirdas Jasinskas $^{1}$, Vytautas Kucinskas ${ }^{1}$, Egle Jotautiene ${ }^{1}$, Imants Ziemelis ${ }^{2}$ \\ ${ }^{1}$ Aleksandras Stulginskis University, Lithuania; ${ }^{2}$ Latvia University of Agriculture \\ algirdas.jasinskas@asu.lt
}

\begin{abstract}
Lithuania medium rotation plant plantations are started to breed relatively recently, so reliable data on suitability of these crops for biofuel production cannot be found. Studies have established wild cherry chop physical properties. 8-16 mm particles make the main, chopped by a drum chopper, wood fraction; on the average, it makes $84 \%$ of total chop mass. Experimental results show that humidity has greater impact on the wild cherry wood chop collapse angle: with decrease of the moisture content the collapse angle increased from $65 \pm 1.0$ to $82 \pm 2.0$ degrees, when humidity is lower, the influence on the natural slope angle is lower. It fell accordingly from $36 \pm 1.0$ to $42 \pm 2.0$ degrees. Chop bulk density variation with the change of wood humidity was determined; with increase of humidity of wild cherry from $35.1 \pm 1.0$ to $6.4 \pm 0.1 \%$ the density varied from $342.67 \pm 4.81$ to $236.67 \pm 2.6 \mathrm{~kg} \cdot \mathrm{m}^{-3}$. Wild cherry ash content is low, and it does not increase $1.87 \pm 0.18 \%$, and the calorific value of wood reached $18.70 \pm 0.36 \mathrm{MJ} \cdot \mathrm{kg}^{-1}$; it is close to the standard accepted in Lithuania - birch caloricity. The determined elemental composition of wild cherry wood showed that carbon (C) quantity reached $49.16 \pm 1.10 \%$, nitrogen $(\mathrm{N})$ quantity does not increase $0.23 \pm 0.10 \%$, and quantity of sulphur (S) does not exceed $0.01 \%$. Having determined and evaluated the main criteria for biofuel (finesse of chop, calorific value, ash content, elemental composition), it is possible to state that wild cherry wood fully complies for production of qualitative biofuel. However, from the economic point of view, it is purposeful to use only branches and tops of wild cherry trees for biofuel, and valuable part of wood may be used for production of furniture or in other industry branches.
\end{abstract}

Keywords: energy plants, medium rotation, biofuel, wild cherry, properties, calorific value.

\section{Introduction}

Lately, mid-rotation hybrid varieties of tree plantations (wood which may be used for production of biofuel) have been bred in Lithuania increasingly. Plantation forest greeneries are bred under intensive technologies aiming to get wood or other products related to woody plants quickly. Plantation areas of these plants in Lithuania are constantly increasing; merely from 2007 to 2014 the declared plantation area has increased by about 10 times and reached 2490 ha $[1 ; 2]$. If the longrotation tree growth expectancy is $30-60$ years, the average rotation hybrid plant growth duration is only $15-20$ years $[3 ; 4]$. The medium rotation plant group includes hybrid poplar and aspen, birch, alder, robinia and wild cherry. Wood of these plants is mainly used for paper, plywood production or extraction of sawn timber. Often, the same species can be grown for biofuel and timber products [5].

Wild cherry (Prunus Avium L.) is considered as one of the viable hybrid plants bred in plantations; it is started to grow in the Lithuanian plantations as well. Wild cherry wood is expensive and valuable, so it is used for production of high quality plywood, wooden furniture and even musical instruments. It is also possible to get high-calorie biofuel from it. Growing of this wood helps bring the optimum economic and environmental protection objectives: to enliven the landscape, reduce air and soil pollution, various species of animals and birds breed in forests [6].

Wild cherry wood is valuable and relatively expensive, but it is purposeful to use the residual biomass (branches and other defective wood) for biofuel. Biofuel market price does not exceed $30 \mathrm{EUR} \cdot \mathrm{m}^{-3}[7 ; 8]$. Annual growth rate of these hybrids tree plantations is $15-20$ solid cubic meters per hectare [2]. $2.5 \mathrm{~m}^{3}$ of valuable timber and about $3.5 \mathrm{~m}^{3}$ of biomass [8], which is reasonable to use for production of biofuel, is obtained from a thirty-meter high tree.

Wild cherry wood properties have been broadly studied; it was found that their densities, depending on the moisture content, range from 490 to $670 \mathrm{~kg} \cdot \mathrm{m}^{-3}$, hardness, according to Brinell, in the longitudinal direction ranges from 51 to 59 , in the transverse direction - 31-32 $\mathrm{MPa}[9 ; 10]$.

According to these indicators, wild cherry wood is very close to oak wood. Wood characteristics of wild cherry are indicated in literature sources; however, we did not find biofuel characteristics indicators. 
Aim of this work: to explore suitability of forest wild cherry wood for biofuel production. To achieve the aim, it is necessary to determine the physical-mechanical properties: bulk density, fractional composition, collapse and natural fall angles, calorific value and ash content of wood chop.

\section{Materials and methods}

Object of the research. Wild cherry wood chopped by the drum chopper Pezzolato PTH 700/660 was used for tests. The chopped wood moisture content was determined in the ASU laboratory by approved methodology [11]. Moisture is removed from the chopped wood in 24 hrs drying it in an oven $2 \mathrm{~B}-15$ keeping a temperature $105^{\circ} \mathrm{C}$. The samples before and after drying and empty dishes are weighted by scales METTLER TOLEDO SB 16001, $\pm 0.01 \mathrm{~g}$ precision.

Determining the bulk density of chopped wood, a cylinder form vessel, volume $0.012 \mathrm{~m}^{3}$, to which chopped wood was poured without pressure, was used. The samples were weighed on scales METTLER TOLEDO SB 16001.

When preparing wood biofuel, the fractional composition of chopped wood (determined by a widespread in the EU methodology) is considered a very important indicator [12]. A set of sieves of $400 \mathrm{~mm}$ diameter was used wherein the sieves with round holes were stacked (in order from the top sieve): $63 \mathrm{~mm}, 45 \mathrm{~mm}, 16 \mathrm{~mm}, 8 \mathrm{~mm}, 3.15 \mathrm{~mm}$ and $1 \mathrm{~mm}$ diameter; $0.5 \mathrm{~kg}$ sample mass sieved by a special sieve shaker Haver EML Digital plus (Fig. 1). The weight remaining on the sieves is weighed, and sample part of every fraction in percent is calculated. Each test is repeated 5 times. The average meaning, average square deviation, confidence interval and test accuracy are calculated. With greater than $5 \%$ test accuracy the number of repetitions is increased.

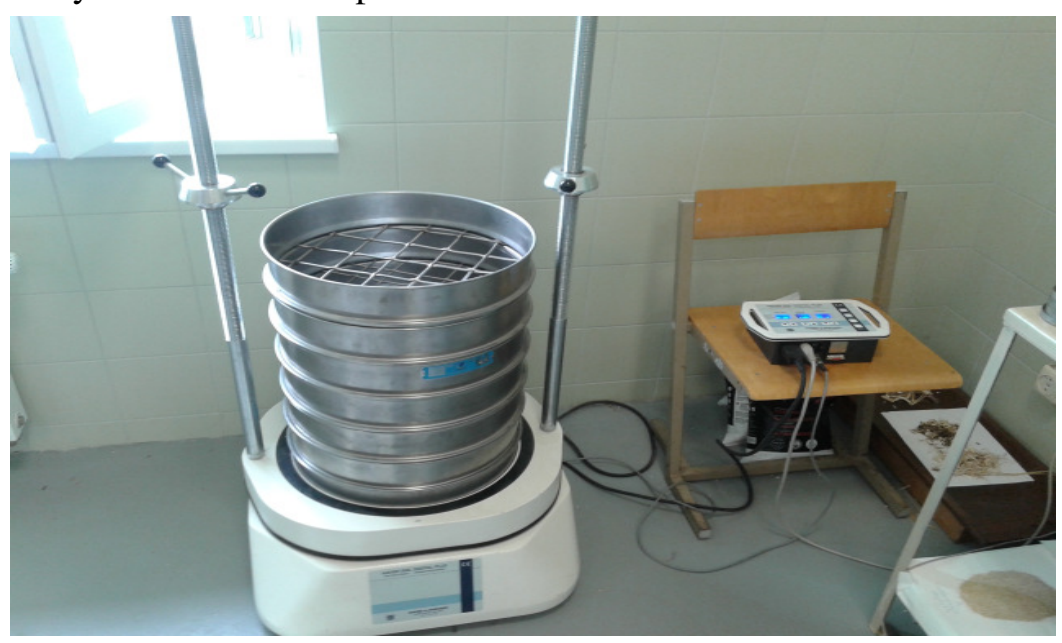

Fig. 1. Sieve shaker Haver EML Digital plus with sieves

When projecting the equipment of chop transportation to furnaces and chop dispensers and accumulation bunkers, as well as determining their constructive parameters, it is vital to determine the chop flow angles. The stand produced in Aleksandras Stulginskis University was used for determination of collapse and natural fall angles; the stand helps determine the natural slope angle $-\alpha_{n}$ and the collapse angle $-\alpha_{g r}[13]$.

Calorific values of wild cherry wood were determined in accordance with an approved research methodology [14]. The following equipment was used for performance of experimental studies: electric laboratory muffle furnace Nabertherm LVT/ 9/11 / P330 No. 258760, measuring range from 0 to $1100{ }^{\circ} \mathrm{C}$, the measurement error of $\pm 10{ }^{\circ} \mathrm{C}$; electronic scales XP2003SDR, No B117433784 measurement accuracy from 0 to $2100 \mathrm{~g}$, measurement error of $\pm 6 \mathrm{mg}$; calorimeter IKA C 5000, No. K39 713430 with calorimetric bomb IKA C 5012, No. 01.501390, measuring range up to $40 \mathrm{~kJ} \cdot \mathrm{g}^{-1}$, measurement accuracy $\pm 0.03 \%$; electronic scales XS205DU/M, No. B045084959, measuring range $0-220 \mathrm{~g}$, measurement accuracy of $\pm 0.2 \mathrm{mg}$.

The upper dry fuel calorific value $Q_{v}$ was found by a calorimeter. Next, we compute the lower calorific value $Q_{a}$ according to the formula presented in literature sources [15]. 
The ash content of chop of wild cherry was determined according to the methodology defined in the standard [16]. Experiments were performed using the equipment used for determination of the calorific value. The ash content of dry mass was expressed as dry mass $\left(A_{\mathrm{s}}\right)$ in percentage.

The research results are presented in a tabular form. To receive separate values, the experimental value $X$ was used; the value received from 3-5 parallel experiments. The experimental data are treated in accordance with the methodologies calculating the average value of series of parallel measurements and the average square deviation of a separate measurement.

\section{Results and discussion}

Moisture content $(w)$ is considered one of the most important wood biofuel qualitative indicators. The moisture content of wood biofuel delivered to boiler-houses in practice ranges from 20 to $40 \%$. The bulk density of wild cherry wood chop $(\rho)$ kept in natural conditions was determined by a chopper Pezzolato PTH 700/660 (Table 1).

Bulk density variations have been evaluated when the wood moisture changed. Moisture of wild cherry wood within 6 months changed from 35.1 to $6.4 \%$ (wood was dried in the room), and the bulk density ranged from $342.67 \pm 4.81$ to $236.67 \pm 2.6 \mathrm{~kg} \cdot \mathrm{m}^{-3}$, i.e. it reduced by approximately $30 \%$. Compared to other mid-rotation hybrid plants (hybrid aspen - Populustremula, robinia pseudoacacia), the bulk density change of wild cherry chop from the humidity values are close.

Table 1

Wild cherry chop moisture content, bulk density and flow angles

\begin{tabular}{|c|c|c|c|c|}
\hline \multirow{3}{*}{ Plant species } & $\begin{array}{c}\text { Moisture content } \\
w, \%\end{array}$ & Bulk density & \multicolumn{2}{|c|}{ Flow angles } \\
\cline { 3 - 5 } & $\rho, \mathrm{kg} \cdot \mathrm{m}^{-3}$ & $\alpha_{n}$ & $\alpha_{g r}$ \\
\hline \multirow{3}{*}{ Sweet cherry } & $35.05 \pm 1.27$ & $342.67 \pm 4.81$ & $36 \pm 1.0$ & $65 \pm 1.0$ \\
\cline { 2 - 5 } & $6.37 \pm 0.07$ & $236.67 \pm 2.6$ & $42 \pm 2.0$ & $82 \pm 2.0$ \\
\cline { 2 - 5 } & Dry matter & 221.71 & - & - \\
\hline
\end{tabular}

Calculating transportation of wood chop, as bulk material, to boiler-houses and storage facilities, it is necessary to know collapse and natural fall angles of the materials. These data are necessary for the establishment of biofuel storage and transportation containers, constructive parameters of bunkers. It was determined that the moisture content of wood chop influences the collapse and natural slope angles. Experiments to determine wildcat wild cherry wood chop flow angles - natural slope $\alpha_{n}$ and collapse $\alpha_{g r}$ angles under the specified humidity have performed (Table 1).

The experimental results show that the moisture content has a large influence on the collapse angle. In the indicated moisture interval, the collapse angle increased on the average by $20 \%$. Lower humidity influence was determined on the size of the natural slope angle. On the average, it increased by $14 \%$ accordingly. Increase of the flow angles with decrease of the wood chop moisture content takes place because of the change of frictional forces of separate wood chop.

Fractional composition of wood biofuel is considered a particularly important qualitative indicator; the size of wood chop should be in the range of 3-100 mm [11]. Having evaluated the fractional composition of chopped wild cherry (sample weight $0.5 \mathrm{~kg}$ ), it was found (Table 2) that the main fraction of wild cherry accumulates on the sieve with a round of 8 and $16 \mathrm{~mm}$ diameter holes, $232.45 \pm 6.65 \mathrm{~g}$ and $187.00 \pm 19.90 \mathrm{~g}$ accordingly. On the average, it makes $84 \%$ of the total mass of the sample. Up to $3 \mathrm{~mm}$ fractional composition does not exceed $4 \%$, which meets the requirements for wood biofuels.

The determined indicators of wild cherry wood chop, ash content $A$ and calorific value $Q_{a}$, are presented in Table 3 . As we can see from the survey results, the wild cherry wood ash content is comparatively small; on the average, it reaches $1.87 \pm 0.18 \%$. Compared to the ash content of other wood types [17], it is close to the poplar and willow wood ash content and smaller than that of average crop rotation plants, as the hybrid aspen and robinia wood ash content. The obtained wild cherry wood calorific values are quite high, about $18.7 \mathrm{MJ} \cdot \mathrm{kg}^{-1}$; they are close to the adopted in Lithuania standard tree - birch wood calorific value [11]. 
Wild cherry wood chop fractional composition

\begin{tabular}{|c|c|c|}
\hline $\begin{array}{c}\text { Fraction size } \\
\varnothing, \mathrm{mm}\end{array}$ & $\begin{array}{c}\text { Fraction mass } \\
M, \mathrm{~g}\end{array}$ & $\begin{array}{c}\text { Fraction mass } \\
M, \%\end{array}$ \\
\hline$<1.00$ & $5.60 \pm 1.5$ & 1.12 \\
\hline 1.00 & $12.50 \pm 4.60$ & 2.50 \\
\hline 3.15 & $44.10 \pm 6.50$ & 8.82 \\
\hline 8.00 & $232.45 \pm 6.50$ & 46.49 \\
\hline 16.00 & $187.00 \pm 4.50$ & 37.40 \\
\hline 45.00 & $1.20 \pm 1.00$ & 0.24 \\
\hline 63.00 & $17.15 \pm 6.0$ & 3.43 \\
\hline
\end{tabular}

Table 3

Parameters of wild cherry wood chop ash content $A$ and calorific value $Q_{a}$

\begin{tabular}{|c|c|c|}
\hline Parameters & Value & $\begin{array}{c}\text { Extended uncertainty, } \\
\pm \%\end{array}$ \\
\hline Ash content, \% & 1.87 & 0.18 \\
\hline Moisture content, $\%$ & 6.41 & 0.07 \\
\hline Dry wood lower calorific value, $\mathrm{MJ} \cdot \mathrm{kg}^{-1}$ & 18.70 & 0.36 \\
\hline
\end{tabular}

The studies have determined elemental composition of wild cherry wood, these results are presented in Table 4.

Table 4

Wild cherry wood chop elemental composition

\begin{tabular}{|c|c|}
\hline Parameters & $\begin{array}{c}\text { Average values } \\
\text { and deviations }\end{array}$ \\
\hline C (carbon) content, \% & $49.16 \pm 1.10$ \\
\hline H (hydrogen) content, \% & $5.81 \pm 0.45$ \\
\hline N (nitrogen) content, \% & $0.23 \pm 0.31$ \\
\hline S (sulfur) content, \% & $<0.01$ \\
\hline O (oxygen) content, \% & 42.93 \\
\hline Moisture content, \% & $6.41 \pm 0.07$ \\
\hline
\end{tabular}

Having analysed elemental composition of wild cherry wood and compared it with other wood types (which are most widely used for biofuel production), it can be said that the carbon content in wild cherry wood is relatively high $-49.16 \%$, and the sulphur content is low $-<0.01 \%$. So, we may conclude that biofuel produced from wild cherry wood obtains a high calorific value and low content of sulphur and nitrogen. When assessing suitability of wild cherry wood for biofuel, the price of raw material should also be taken into account (Table 5).

Wood logs purchase prices in Lithuania (14.04.2016) [18]

Table 5

\begin{tabular}{|c|c|}
\hline Raw wood species & Wood prices, EUR· $\mathbf{m}^{\mathbf{3}}$ \\
\hline Fir logs & 75 \\
\hline Pine logs & 66 \\
\hline Alder logs & 64 \\
\hline Birch logs & 121 \\
\hline Aspen logs & 52 \\
\hline Oak, robinia, sweet cherry logs & 242 \\
\hline
\end{tabular}

Based on the study results, the prices of wood logs [18] and biofuel [7;8], economic viability of wild cherry use for biofuel may be grounded. 
Comparing the price of $1 \mathrm{~m}^{3}$ of logs of wild cherry with the quantity of biofuel obtained from $1 \mathrm{~m}^{3}$ of pure wood $\left(2.5 \mathrm{~m}^{3}\right.$ of chop), we see that the price of $1 \mathrm{~m}^{3}$ of wood logs is on the average 3.0 times higher than the costs of the derived from it biofuel. Therefore, evaluating the presented data and taking into account the purchase prices, it is purposeful to use wild cherry branches and tops for biofuel (which accounts for approximately $60 \%$ of wood biomass [8]), and it is purposeful to use valuable wood timber for furniture and other various industries.

\section{Conclusions}

1. Evaluating the quality of wood chop prepared by a drum chopper, it has been determined that the biggest part of wood chop of wild cherry consists of 8 to $16 \mathrm{~mm}$ size fractions, representing an average of $84 \%$ of the chopped mass.

2. The experimental results show that the moisture content has a greater impact on the collapse angle of wild cherry wood chop. Decreasing moisture, the collapse angle increased from $65 \pm 1.0$ to $82 \pm 2.0$ degrees. Lower humidity influence was set for the size of the natural slope angle. It varied accordingly from $36 \pm 1.0$ to $42 \pm 2.0$ degrees.

3. The ash content of wild cherry is low; it reached $1.87 \pm 0.18 \%$; the calorific value was comparatively high, it was $18.7 \pm 0.36 \mathrm{MJ} \cdot \mathrm{kg}^{-1}$. These indicators are close to the adopted in Lithuania standard for biofuel production - birch indicators. Having identified and assessed the main biofuel criteria (chop fineness, calorific value, ash content, and elemental composition), we can say that wild cherry wood is perfectly suitable for production of high-quality biofuel.

4. Evaluating the wild cherry wood characteristics and raw wood price, it may be recommended to use branches and tops of wild cherry for biofuel production, and valuable wood may be used for furniture and other industries.

\section{References}

1. Lietuvos biokuro potencialo vertinimas, degalų kainų prognozès, biokuro naudojimo socialinio vertinimo nauda ir biokuro panaudojimo valstybès vystymuisi intervenciniai pasiūlymai (Assessment of Lithuania biofuel potential, fuel price forecast, biofuel use social evaluation of the benefits and use of biofuel for the development of state intervention proposals). [Acessed 04/12/2015]. Available at: http://www.ebb-eu.org/legis/LITHUANIA_3rd/20report/20Dir2003 _30_report_LT.pdf (in Lithuanian).

2. Aleinikovas M. Plantacinė miškininkystè ir nepanaudotos biomasès resursai (Plantation forestry and unused biomass resources). Tarptautinès biomasės energetikos konferencijos: Technologijos. Tendencijos. Sprendimai. Vilnius, 2014, 30 p. (In Lithuanian).

3. Biokuro potencialas: 1 dalis (Biofuel potential: Part 1). [Acessed 15/12/2015]. Available at: http://www.paksiluma.lt/index.php/naujienos/43-biokuro-potencialo-1-dalis (In Lithuanian).

4. Recommendations of plantation forest planting, cultivation and usage: 2006. [Acessed 10/10/2015]. Available at: http://www.infolex.lt/lite/ta/52249.

5. Bartkevičius E., Pliūra A., Suchockas V. Plantacinè miškininkystè pasaulyje ir jos perspektyvos (Plantation forestry in the world and its prospects). Mūsų girios, Vol. 1, 2013, pp. 8-11 (In Lithuanian).

6. Pretzsch H., Nickel M., Dietz E. Wachstum und waldbauliche Behandlung der Kirsche in Abhängigkeit von den Standortsbedingungen - Bayerische Landesanstalt für Wald und Forstwirtschaft (Growth and forestry treatment of the cherry depending on the site conditions Bavarian State Forestry and Forestry Agency) (LWF) -Wissen. 65, 2012, S.13-23 (In German).

7. Waldwirtschaft 2011, Privat-Waldinfo fur den Ortenaukreis (Forestry 2011, private forest information for the Ortenaukreis), 211, $44 \mathrm{~s}$. (In German).

8. Grote R., Schuck J., Block J., Pretzsch H. Oberirdische holzige Biomasse in Kiefern-/Buchenund Eichen-/ Buchen- Mmischbestanden (Upper-earth woody biomass in pine / beech and oak / beech mixes). Forstw. 122, 2003, pp. 287-301. (In German).

9. Jeske H., Grosser D. Das Holz des Kirschbaums-Eigenschafen und Verwendung (The wood of cherry tree peculiar and use). LWF Wissen. 65, 2012, pp. 64-69. (In German). 
10. Schott K. M. Anzucht von außergewöhnlichen Pflanzenqualitäten der Wildkirschen (Cultivation of extraordinary plant qualities of wild cherries). Available at: http://www.waldwissen.net, 09.12.2010. Online-Version (In German).

11. Vares V., Kask U, Muiste P., Pihu T., Soosaar S. Biokuro naudotojo žinynas (Biofuels User's manual). Vilnius, 2007, 188 p. (In Lithuanian).

12. LST CEN/TS 15149-2.2006. Kietas biokuras. Dalelių matmenų pasiskirstymo nustatymo metodai (Solid biofuels. Particle size distribution determination methods). 2006, 14 p. (In Lithuanian).

13. Jasinskas A., Zvicevičius E. Biomasès gamybos inžinerija. Mokomoji knyga aukštosioms mokykloms (Biomass production engineering. Educational book for higher education). Akademija, 2008, 98 p. (In Lithuanian).

14. CEN/TS 14918.2006/P.2008. Kietas biokuras. Šilumingumo nustatymas (Solid biofuels. Determination of calorific value). LST. 2008, 26 p. (In Lithuanian).

15. Šateikis I., Lynikienè S. Dizaino skaičiavimai atsinaujinančių energijos šaltinių naudojimui. Metodiniai patarimai (Design calculations of renewable energy sources usage. Methodical applies). Kaunas-Akademija-Raudondvaris, 2007, 48 p. (In Lithuanian).

16. LST CEN/TS 14775.2005. Kietas biokuras. Peleningumo nustatymas (Solid biofuels. Ash content determination method). 2005, 16 p. (In Lithuanian).

17. Puida E. Kietojo biokuro energetinès charakteristikos, identifikavimas, naudojami metodai, standartai ir techninė ịranga (Solid biofuel energy characteristics, identification, used methods, standards and hardware). [Acessed 10/03/2016]. Available at: http://www.lsta.lt/files/seminarai/131212_AVGO/E.Puida (In Lithuanian).

18. Forest Exchange. The price of wood. [Acessed 14/04/2016]. Available at: http://www.miskobirza.lt/categories/forest_price_info. 